\title{
THE LOCAL FOOD SECURITY SYSTEM IN REGENCY OF TIMOR TENGAH SELATAN (TTS)
}

\author{
By: Nursalam \\ Lecturer in Departemen of Public Administration, Faculty of Social and Political Sciences, \\ Nusa Cendana University, Kupang, Indonesia \\ Email : nursalamjeppu@yahoo.com
}

\begin{abstract}
Timor Tengah Selatan regency (TTS), Nusa Tenggara Timur (NTT) Province is one of the areas in NTT that often have food security problems such as availability, access and utilization of food; problem of availability is often caused by low food production due to little rainfall; access to difficult food due to poor infrastructure conditions; and food use is caused by the ability to process food traditionally. The problem statement in this study is whether there is a system of local food security on community at the regency of Timor Tengah Selatan. The research purpose achieved through this research was to find out the Local Food Security System of the people in the Timor Tengah Selatan regency. whereas the research method uses qualitative research methods. The technique of determining informants was done purposively. So that the informant consists of; farmers, traditional leaders, village and sub-district government officials, and officials from the Food Security and Counseling Agency in Timor Tengah Selatan regency. The data collection techniques include; in-depth interviews, participant observation, and relevant documentation techniques, regulatory documents and meeting resumes in the efforts of local food security in the South Timor Tengah regency.The results of the study show that there is a system of food security in the community, namely the system of availability, access and utilization of local food. In the system, their availability has food barns which contain corn and peanuts. Whereas in access to food they are familiar with a system of symbolic interactions if people have difficulty getting food. In terms of food utilization they have various ways of processing local ingredients into foods that have high nutritional value.The recommendations suggested in this study are for regional governments to pay attention to community values that support the local food security system.
\end{abstract}

Keywords: Food Security, Local Community, and Values 


\section{Introduction}

The food is one of the most basic human basic needs. accessibility, and the quality of food consumed by the public is an important measure to see how much food public. The World Food Conference in 1996, defines food security as food availability. Food security exists when all people at all times have physical and economic access to sufficient, safe and nutritious food to meet their dietary needs and food preferences for an active and healthy life. At the level of individuals and households food availability is sufficient and there are choices for them to determine the food they want in order to support an active and healthy life (Bingxin at al, 2010). The definition of food security is further expanded to access to food, availability, utilization and stability of food at the individual and household level (Clay 2002), in this paper the food security system is a system consisting of supply, distribution and consumption subsystems.

Food shortages will cause a variety of impacts on the public, which can lead to food shortages which have implications for people's malnutrition. as well as the condition of food security in Timor Tengah Selatan regency which is one of the regency in East Nusa Tenggara province which often experiences food security problems such as food shortages caused crop failures, food distribution problems by limited infrastructure, and food use problems.

The problem of public food security in Timor Tengah Selatan regency can be seen from the data that the average food consumption of the population of the Timor Tengah Selatan Regency is still below the expected energy sufficiency rate 2.065 $\mathrm{kcal} /$ person/day ((76,71 nutrition adequacy rate) in the period 2015-2017 or during the period 2015-2017 there is a decrease in food consumption as much as $10.46 \%$ (Agency of Food Security, Timor Tengah Selatan Regency, 2018)

The decline in food consumption can also be seen from the decline in local food crop production as in table 1.

Table 5.6: Local Food Production in Timor Tengah Selatan Timor Regency 2013-2015 (Ton)

\begin{tabular}{|l|l|c|c|c|}
\hline \multirow{2}{*}{ No } & \multirow{2}{*}{ Food Type } & \multicolumn{3}{|c|}{ Year } \\
\cline { 3 - 5 } & & 2015 & 2016 & 2017 \\
\hline 1 & Maize & $61.580,37$ & $54.434,23$ & $58.123,28$ \\
\hline 2 & Cassava & $28.281,95$ & $25.391,40$ & 25.391 \\
\hline 3 & Sweet potato & 145 & 138 & 138 \\
\hline
\end{tabular}

Source: Agency of Food Security, Timor Tenga Selatan Regency, 2018

Actually, the harvested area of local food crops being explored in Timor Tengah Selatan Regency is $45 \%$ of the potential for harvesting local food crops 51,000 ha (Agency of Food Security, Timor Tengah Selatan Regency, 2018)

Another problem faced is food distribution due to the location of a very remote area making it difficult for food distribution from the province to the regency, from the regency to districts and sub-districts in the South Timor Tengah regency. People living in 
rural areas experience food insecurity because of irregular food delivery problems, nutritional choices of food delivered are limited and the quality is low, the price is high, and the supply capacity is insufficient with the food needs of the public.

Therefore, the problems faced in dealing with food security in Timor Tengah Selatan district are; (a) production and production capacity are increasingly limited; (b) limited basic rural infrastructure; (c) inadequate food distribution facilities and infrastructure to connect the location of producers to consumers; (d) limited family economic capacity so that it influences their purchasing power on food.

\section{Perspectives of Food Security}

Food security is a perception of the situation of relations between humans and the need for food. Food is a commodity that is commonly eaten by humans to fulfill their daily needs. Until now, the concept has undergone many changes, namely happening at the global, national, household and individual levels, from the perspective of food as a basic need to a livelihood perspective and from objective indicators to subjective perceptions (Lassa, 2009: 10).

According to Timmer (2003) the perception of food security will probably be clearer if we approach it from the opposite side by imagining the situation of food insecurity. The food situation in an area is vulnerable if there is people in the region having difficulty in obtaining basic food needs for the survival of their lives. Food in the concept of food security be interpreted as the staple food of a society discussed, not all alternative food. The main food different from one community to another according to the differences in their respective cultures. In addition the perception of staple foods will also vary according to the level of income in the same community.

In the context of the relationship between humans and food, the relationship that needs to be considered in the analysis of food security is actually the relationship between humans and humans to food. Food consumed by X today is food that cannot be consumed by other people, and vice versa. Therefore food security is a product of the relationship between people and people, and not people with food. Food security is always social context, this is based on the condition that food security needs to be achieved for reasons of (1) the food security situation is itself a safe situation; (2) food security is needed especially in facing the uncertainty of food production in the future.

Maltusans argue that food insecurity and hunger are merely a matter of production and availability, but this was disputed by some food experts among Dreze and Sen (1989) who stated that food insecurity and hunger occurred due to the lack of access to food. In an economic structure where the transaction process is a medium for flowing food flows from one party to another, food security is conditioned by factors that determine mutual relations between people and people through the transaction process. These factors include; (a) ownership of something including labor or an item (money) that can be exchanged for food; (b) natural disasters that can destroy agricultural production such as droughts, floods or pest attacks; (c) political instability, and; (d) other changes outside the food system;

Since 1980, the discourse on food security has been dominated by food entitlements, risks and vulnerabilities. According to Maxwell (1996: 155) and Lassa 
(2009: 11) there are at least four elements of sustainable food security, namely: (a) food sufficiency defined as the number of calories needed for active and healthy life; (b) access to food, which is defined as the right of entitlements to produce, buy or exchange food or receive as gifts; (c) resilience which is defined as a balance between vulnerability, risk and social security guarantees; (d) the function of time when food security can be chronic, transitional and cyclical.

different from Timmer (2005: 2) food security exists when all people at all times have physical and economic access to meet sufficient food needs in life for production and health. According to Timmer (2005: 2) that food security has three dimensions, namely: (a) food availability is sufficient in terms of food quality and supplied through domestic and imported production; (b) access by households and individuals to obtain food properly; (c) food use through adequate food, clean water, sanitation and health care.

\section{Study about Food Security}

\section{Research on Food Institutions}

Research conducted by the Food Research Team of the Society and Culture Research Center and the Center for Economic Research found that the need to establish food institutions in the form of rice and non-rice food banks in order to realize community food security. The non-rice food institution is a forum consisting of institutional elements that are in the supra community, namely the Food Sovereignty Council whose members come from peasant leaders. The Food Sovereignty Council always coordinates with government elements, including village heads, agriculture instructor and government officials in agriculture. The position of the Food Sovereignty Council is in the sub-district area, and has the duty to direct the non-rice food bank organization in formulating programs and activities for non-rice food banks, covering aspects of availability, distribution, and consumption, and diversification of food to realize the independence and food sovereignty of the community (PMB-LIPI, 2001)

The Food Sovereignty Council must be fully supported by community leaders, because food institutions have important visions and missions, namely want to restore the local food system that has disappeared since the enactment of the rice self-sufficiency policy.

Research results indicate that there are obstacles faced in the development of food institutions, namely: (a) availability of arable land, the rental price of arable land in the market, which is equivalent to 4.5 tons of GKG (price in 1998) is too expensive if converted in rupiah; (b) ndependence of groups that are difficult to develop. Many factors influence it, including the low education of members of food banks and the unavailability of social capital (social networking; mutual cooperation; low social trust), ack of access to the government to own cultivated land, both in the form of information and bargaining power; poverty factor; It's hard to get people who are able to become leaders among them;(c) farmer's mentality, the work of farm workers who are accustomed to working with a daily wage system becomes a barrier factor to foster new awareness, that they must be patient to wait for results in each harvest season. 


\section{Research on Local Food Security}

The research conducted by Sukiono et al (2009) with the title: Study of Local Concepts of Food Security and Probability of Household Food Insecurity (Study on Fisherman Households and Rice Farmers in Mukomuko Regency, Bengkulu Province).

Research on food security has been more focused on measuring household food security, the link between household attributes and food security as well as determinants of factors. he relation between household attributes and food security as well as determinants of the factors. Measures of household food security that are often used are more commonly used generic indicators, such as calorie intake (adequate calories), poverty, food availability and so on. The household food security also concerns the social and cultural dimensions of local communities, including their economic dimensions.

On the other hand, the use of generic indicators often cannot describe the actual situation of household food security, apart from being caused by neglecting the social and cultural dimensions, as well as existing generic indicators or those implemented are generalizations. Therefore, identifying and formulating local concepts of food security becomes significant so that it can not only enrich indicators of household food security but also the repertoire of knowledge and research on household food security that has social and cultural insight.

Furthermore, this research is expected to be able to find a link between the attributes possessed by households and the tendency for household food insecurity. It is important not only to be able to formulate a more location specific food security policy but also can be used as a reference for researchers in the field of food security and subsequent food policies (Sukiyono et al, 2009).

The results showed that, found that the community of fishermen and rice farmers defined food security as a work concept. Understanding this work concept is defined as an effort to produce and or obtain consumer goods in this case is food. The implication is that the level of food security or food insecurity is determined by the demands of their work. The community of fishermen and rice farmers also categorizes the variety of foods based on their importance in context when they do work. Furthermore, they categorize food into three types, namely food that must be available every day, food that should be available every day and food that does not have to be there every day.

Departing from this concept, household food security is operationalized in the form of food availability for the type of food that must be available every day, namely rice and fish for fishing households and rice and vegetables for rice farming households. For fishermen households, the rice that must be available is $1.75 \mathrm{~kg}$ per capita per week and fish is $0.25 \mathrm{~kg}$ per capita per day. Meanwhile, for rice farming households, they will feel comfortable if the rice in their household is at least $6 \mathrm{~kg}$ per capita per year and vegetables are Rp. With this indicator, the number of vulnerable fisherman households is 56 percent while the number of rice farmer households is 48 percent. These results indicate that fishing households have a high probability of experiencing food insecurity compared to rice households. 


\section{Research on Strengthening Regional Food Security}

The study conducted by Safrizal (2009) with the title: Strengthening regional food security: Study of the revitalization of food security institution of Gampong community in Aceh Besar Regency. Based on this study, information is obtained that there has been a change in the management of food for the community towards a more economical and pragmatic manner so that the institutional function as an instrument to strengthen food security of the community becomes marginalized. Therefore it is necessary to revitalize institutions to restore food security to the real conditions, namely sustainable food security and household-based. Institutional revitalization includes not only values and norms but also institutional structures.

The results of Safrizal (2009) show that the performance of the household food security system has deteriorated, where food reserves have not been a household priority so that availability is not maintained continuously, public consumption patterns are still focused on rice, not reflecting food diversification and causing dependence on rice very high. Food distribution between households in the form of rice borrow is constrained by distrust, returns often do not meet the quality and quantity of food borrowed. The decline in food security is caused by changes in the consumptive behavior of farmers in managing production, the perception of making rice as the main food, the low motivation to farm, especially young people, as well as the influence of middlemen in farming systems.

Optimizing the role of each change actor can be done through more intensive social interactions, the legitimacy of the relevant unwritten rules to Qanun Gampong is urgently needed so that the determination of social sanctions can be enforced, social potential such as mutual cooperation, high social awareness is capital.

Finally this research offers an institutional model as an instrument to strengthen the food security of the Gampong community, namely Meunasah Barn. To carry out this model is not solely the task of farmers as the focus of change, but the involvement of all elements of the Gampong community. We all have a moral obligation to make it happen, because actually the revitalization of food security institutions is essentially a revitalization of humanity, because food issues are a matter of human rights.

\section{Research on the Implementation of Food Security Action Programs}

Research conducted by Sutoyo (2013) with the title: Implementation of the Food Resilience Action Program in Bengkulu province to describe and analyze a model of synergy between the Central Government and the Provincial Government of Bengkulu that is effective in producing food security, implementing an action program on food security in Bengkulu Province.

The results of the study show that complex food security with the interrelationship between many actors and regions with the dynamics of change over time, good coordination and synergy is the key to the success of development.

To carry out the coordination and synergy the government established a Food Security Council through Keppres Nomor 132 Tahun 2001 which regulates coordination, evaluation and control of efforts to realize national food security. To date, 32 Provincial 
Food Security Councils have been formed and 339 regencies / municipal Food Security Councils have been formed.

\section{Research methods \\ 1. Research Design}

This study apply a qualitative approach, the qualitative term refers to processes and meanings that are not rigorously tested or measured, both in terms of quantity, intensity, and frequency. Emphasis is placed on the nature of social construction and reality and seeks answers to how social experiences are shaped and given meaning (Denzim and Lincoln, 1994: 47). The main emphasis on the qualitative approach in this study is based on consideration, that the focus of this study reveals the food security of local communities. research that focuses on the disclosure of relevant processes is a qualitative approach.

In addition to describing the process of the model used in relation to public food security. this research also reveals seeing the context, in this case the context of local people's food security as a setting for the process. For local community food security, interpretation of the meaning and interpretation of actions is needed. Disclosure of processes and interpretation of the meaning of qualitative approaches is more relevant (Creswell: 1994).

\section{The Process of Determining Informants}

Determination of research information was done purposively, deliberately determined by considering that those selected knew exactly about the local community food security system, namely; family heads, village government officials, and officials of the Agency Food security of Timor Tengah Selatan Regency, experts in food security.

\section{Results and Discussion}

1. Research Result.

\section{a. Performance of the Food Security Agency}

The performance of the Food Security Agency of Timor Tengah Selatan Regency can be seen from the achievement of the targets set. The performance indicators used in measuring the performance of the Food Security Agency can be seen in the achievement of targets and financial accountability, as shown in table 2 
Table 2: Results of Food Security Performance Measuremen in 2017

\begin{tabular}{|l|l|l|}
\hline No & \multicolumn{1}{|c|}{ Target } & achievements (\%) \\
\hline 1 & Development of Food Independent Villages & 99,50 \\
\hline 2 & Development of Village Food Storage & 95,60 \\
\hline 3 & Increased Food Reserves & 22,20 \\
\hline & Average & 72,43 \\
\hline
\end{tabular}

Source: Agency of Food Security, Timor Tenga Selatan Regency, 2018

Based on Table 2 shows that the average achievement score obtained is $72.43 \%$, which is measured by the target of developing autonomous food villages, developing village food barns, and targets for increasing food reserves. The achievement of financial Development of Food Independent Villages financial accountability can be seen as table 3.

Table 3: Achieving Performance of Food Security Based on Absorption 2015 Budget

\begin{tabular}{|l|l|l|l|l|}
\hline No & Performance Indicator & Allocation & Realization & $\%$ \\
\hline 1 & Food Utilization & 68.570 .000 & 67.862 .500 & 98,97 \\
\hline 2 & $\begin{array}{l}\text { Development of Food } \\
\text { Outonomous Villages }\end{array}$ & 126.407 .000 & 125.882 .500 & 99,59 \\
\hline 3 & $\begin{array}{l}\text { Development of Village Food } \\
\text { Storage }\end{array}$ & 443.863 .500 & 424.400 .000 & 95,61 \\
\hline Total & 638.840 .500 & 618.145 .000 & 96,76 \\
\hline
\end{tabular}

Source: Agency of Food Security, Timor Tenga Selatan Regency, 2018

Based on table 3 shows that the ability of the apparatus in implementing the budget in the framework of food security in Timor Tengah Selatan Regency is quite high. Absorption of the budget reached $96.76 \%$ with the realization of $618,145,000$ million rupiah originating from the district budget of Timor Tengah Selatan regency.

The program implemented to carry out the budget included among others; (a) yard utilization program; (b) autonomous food village development program and; (c) village food barn development program. Whereas programs that use co-administration funds are programs;(a) program of availability and handling of Food Insecurity; (b)program of management and technical support. for more details about the accountability of co-administration financial performance in table 4.

Table 4: Achievement of Food Security Performance Based on 2017 Budget Assistance Program

\begin{tabular}{|l|l|l|l|l|}
\hline No & \multicolumn{1}{|c|}{ Program } & allocation & realization & $\%$ \\
\hline 1 & $\begin{array}{l}\text { Food Vulnerable Availability and } \\
\text { Handling Development Program }\end{array}$ & 278.667 .000 & 268.615 & 96,00 \\
\hline 2 & $\begin{array}{l}\text { Management and technical support } \\
\text { program }\end{array}$ & 30.600 .000 & 30.600 .000 & 100 \\
\hline & Total & 309.267 .500 & 299.215 .000 & 97,00 \\
\hline
\end{tabular}

Source: Agency of Food Security, Timor Tenga Selatan Regency, 2018 
Table 4 shows that the budget realization reached $97 \%$ or as much as $299,215,000$ million rupiah.

\section{b. Description of local Food Security in South Timor Tengah Regency}

The food security is produced by a food security system covering 3 dimensions, namely: (a) available food in sufficient quantities and types for the entire population; (b) equitable and affordable food distribution and; (c) food consumption or food utilization by each individual who meets the nutritional adequacy and quality standards.

The food security program implemented in TTS Regency aims to empower the community to be able to maximize local community food. The description of the implementation of community food security in TTS Regency can be seen in aspects:

\section{Dimensions of food availability}

Food security is the ability to ensure that all people obtain sufficient, quality, safe, and halal food, which is based on optimizing the use and diversity of local resources. Regarding local food availability in the Timor Tengah Selatan regency can be seen in table 5 .

Table 5 : Ketersediaan pangan Lokal Kabupaten Timor Tengah Selatan Tahun 2013-2015 (Ton)

\begin{tabular}{|l|l|c|c|c|}
\hline \multirow{2}{*}{ No } & \multirow{2}{*}{ Food Type } & \multicolumn{3}{|c|}{ Year } \\
\cline { 2 - 5 } & Maize & 2015 & 2016 & 2017 \\
\hline 2 & Cassava & $82.750,39$ & $74.534,23$ & $70.323,27$ \\
\hline 3 & Sweet potato & $243.783,95$ & $42.261,40$ & 41.591 \\
\hline
\end{tabular}

Source: Agency of Food Security, Timor Tenga Selatan Regency, 2018

Based on table 4.6 about local food production shows the availability of local food in the Timor Tengah Selatan regency. Production data shows a downward trend from 2015 to 2017 . This condition certainly threatens the sustainability of food supplies and needs by the local community.

The challenges faced regarding the problem of pagan supplies in the Timor Tengah Selatan regency are: (a) food production capacity is increasingly limited due to conversion of agricultural land to non-agricultural use; declining quality and fertility of the land; increasingly limited and uncertain water availability; (b) the amount of food demand is increasing, along with the increase in population, fulfillment of industrial raw material needs, and the development of food use along with the development of tourism; (c) there is competition for the use of food for bio-energy and animal feed; (d) Making and empowerment of food independence in food insecure villages and food insecure community groups due to facilities and infrastructure constraints as well as the ability of HR assistants and field extension workers.

Based on the strategic plan of the Food and Food Security Agency of South Timor Tengah regency, the strategic steps taken to deal with various problems of the food supply are; (a) utilize available analytical tools to develop the potential of local food and 
the culture of a diverse society; (b) develop community motivation and participation in diversifying local food through empowering home industries, food processing technology;(c) the development of cooperation with higher education institutions, NGOs and professional organizations to support the accelerated diversification of food and nutrition (DPG) programs;(d) utilization of the food security system to increase knowledge, awareness of the community to consume diverse, nutritious and balanced food.

\section{Dimensions of Distribution and Access to Food}

Stability indicators Food supply and prices are indicators included in the dimensions of distribution and access to food. The problems associated with this dimension are inadequate distribution facilities and infrastructure to connect the location of producers with consumers throughout the region which causes a lack of guaranteed smooth flow of food distribution. This can obstruct people's access to food so that it can reduce the quality of food consumption.

Food problems are indeed very complicated things, because they are basic human needs that must be met. The government is obliged to ensure that the distribution and access to food can be done by the community. The food security policy is intended as an effort to provide sufficient and distributed food at affordable prices so that it is easily accessible to the public.

The description of food distribution and access can be seen from the condition of the infrastructure and business actors in the local food sector as listed in table 6

Table 6: Local Food Business Data in Timor Tengah SelatanRegency

\begin{tabular}{|l|l|l|}
\hline No & Businessmen & Amount \\
\hline 1 & Farmer & 132.334 \\
\hline 2 & Merchant & 208 \\
\hline 3 & Farmers Group & 1.838 \\
\hline 4 & Farmers Association & 163 \\
\hline 5 & processing business & 3 \\
\hline 6 & Praditional Market & 42 \\
\hline 7 & Stall & 158 \\
\hline
\end{tabular}

Source: Agency of Food Security, Timor Tenga Selatan Regency, 2018

Based on the table above shows that the number of farmers who cultivate local food as many as 132,334 people who are members of 1838 farmer groups spread in 32 districts in the regency of Timor Tengah Selatan. In addition to their own crops, their harvests are also partially marketed in traditional markets with 208 traders and 158 shops.

Various problems in Timor Tengah Selatan regency relating to distribution and access to food include those related to food distribution institutions such as farmer groups, joint farmer groups (Gapoktan), cooperatives, community food stores, entrepreneurs. On the other hand there are also weaknesses in the distribution of food, where the existing marketing institutions have not carried out their functions properly, 
causing inequality in marketing. So that a strategic step is needed, namely by activating the role of distribution and marketing institutions.

\section{Dimensions of Food Consumption and Utilization}

The dimensions of food consumption and utilization in the Timor Tengah Selatan regency are still low, this is because various problems include: (a) limited family economic potency; (b) limited knowledge and awareness about food and nutrition; (c) trend to decrease the proportion of local food-based food consumption decreases; (d) influence of cultural values of eating habits that are not in harmony with the principles of diverse food consumption, balanced nutrition, and safe

The description of the pattern of local food consumption in Timor Tengah Selatan regency can be seen from the pattern of hopeful food (PPH) as in table 7

Table 7: Pattern of Hope Food (PPH) Local Food Consumption in Timor Tengah SelatanRegency

\begin{tabular}{|l|c|c|c|c|c|c|}
\hline Food Group & Calory & $\%$ & $\begin{array}{c}\% \\
\text { AKG }\end{array}$ & $\begin{array}{c}\text { Actual } \\
\text { Score }\end{array}$ & $\begin{array}{c}\text { Maximum } \\
\text { score }\end{array}$ & $\begin{array}{c}\text { Score } \\
\text { PPH }\end{array}$ \\
\hline Grains & 1.015 & 46,14 & 46,1 & 23,1 & 25,0 & 23,0 \\
\hline Tubers & 94,4 & 4,29 & 4,3 & 2,1 & 2,5 & 2,5 \\
\hline Nuts & 81,5 & 3,70 & 3,7 & 7,4 & 10,0 & 10,0 \\
\hline $\begin{array}{l}\text { Vegetables \& } \\
\text { Fruits }\end{array}$ & 92,2 & 4,19 & 4,2 & 21,0 & 24,1 & 24,1 \\
\hline Amount & $1.283,1$ & 58,32 & 58,3 & 53,6 & 61,6 & 61,6 \\
\hline
\end{tabular}

Source: Agency of Food Security, Timor Tenga Selatan Regency, 2018

Based on the above data the achievement of local food consumption in TTS regency reached 1,283.1 kcal / per capita / day. When viewed from the percentage of performance of each group's contribution, the achievement of the grain group has exceeded the PPH standard. while the tubers food group has not yet achieved the PPH score which is only 2.1 , the maximum score to be achieved is 2.5 . Thus the tubers food group has not yet reached the level of nutrient adequacy at the consumption level.

On the other hand, in the framework of supporting the development of aspects of consumption and utilization of food, there are several problems including: (a) limited facilities and infrastructure and human resources to conduct studies on consumption and utilization of local food, quality and food security, availability of data; (b) the lack of action review on the results of motivational activities and community participation

\section{Discussion}

\section{Food availability}

Provision of food in sufficient quantities to meet the needs of the entire population and in accordance with the requirements for nutritional quality is one of the important problems, as well as the availability of food data that can describe food availability. 
The results of the analysis of food availability in the Timor Tengah Selatan regency over the past three years indicate that it has not met the availability standard, which is 2,200 / kcal / per capita / day. The results of the analysis of food availability in the TTS district over the past three years indicate that it has not met the availability standard, which is 2,200 / kcal / per capita / day.

This data shows that the ideal score in accordance with the expected food pattern standards has not been fulfilled. One aspect that is quite influencing food availability is food productivity in Timor Tengah Selatan regency, data shows that productivity has not been maximized due to the maximum planting area and harvest area. Based on the data obtained about planting area, harvest area, and local food productivity shows that food productivity is not optimal because there is still a difference between harvest area and planting area.

Based on the results of interviews with informants at the Timor Tengah Selatan regency Food Security Agency, the occurrence of this difference was due to drought that occurred in several districts. In Timor Tengah Selatan regency, rainfall only lasts 4 months, namely December to March. The rest is the dry season, which is from April to November. The consequences of this musin, in 2015 are as in table 8 .

Table 8: Food Deficiency Data in Timor Tenga Selatan Regency in 2018

\begin{tabular}{|c|l|l|}
\hline No & Situation & Amount and Percentage \\
\hline 1 & Number of Districts Affected & $16(50 \%)$ \\
\hline 2 & Number of Village Affected & $105(36,32 \%)$ \\
\hline 3 & Number of family heads & 54.292 \\
\hline 4 & Number of Head of Families who are victims & 17.711 \\
\hline 5 & Area of Damage & $15.882(\mathrm{Ha})$ \\
\hline 6 & Heavy Transients & 57 Desa $(19,79)$ \\
\hline 7 & Light Transient & 48 Desa $(16,61)$ \\
\hline
\end{tabular}

Source: Agency of Food Security, Timor Tenga Selatan Regency, 2018

On the table above it is proof that community food security needs to be improved. Dry musin hit the Timor Tengah Selatan regency with a broad impact affecting food supply, access and utilization. The Timor Tengah Selatan Regency has a total of 32 districts, $50 \%$ or 16 districts in 2015 were hit by a drought in which 54,292 households were affected. Whereas the most severely affected districts are as shown in table 9 
Table 9: Districts that have the most Food shortages

\begin{tabular}{|c|l|l|}
\hline No & \multicolumn{1}{|c|}{ District } & \multicolumn{1}{|c|}{$\begin{array}{c}\text { Number of villages } \\
(\%)\end{array}$} \\
\hline 1 & Amanatun Selatan & $13(100 \%)$ \\
\hline 2 & Kie & $8(100 \%)$ \\
\hline 3 & Toianas & $9(100 \%)$ \\
\hline 4 & Noebana & $4(67 \%)$ \\
\hline 5 & Nunkolo & $5(44 \%)$ \\
\hline 6 & Amanuban Selatan & $4(40 \%)$ \\
\hline
\end{tabular}

Source: Agency of Food Security, Timor Tenga Selatan Regency, 2018

The data in table 9 shows that among 32 districts there are four (4) districts that have the most drought, so crop failures and food shortages occur in the district, namely in the Amanatun Selatan district, in 13 villages, Kie district occurs in 8 villages and the Toinas district occurred in 9 villages.

Although the condition of food shortages is experienced by people in the Timor Tengah Selatan regency, however, in this area there has never been a hungry, where people experience very severe food conditions which cause the community to die due to lack of food.

The research findings show that the community has its own mechanism to maintain food reserves through the Food Barn. Food barns are institutions belonging to village communities engaged in the deviation, distribution, processing and trade of food that is formed and managed by the community. The institutional conditions of food barns in Timor Tengah Selatan regency have not been too developed and are still traditional, the number of food storage groups is 15 groups.

\section{Food Distribution}

Effective food distribution is strongly supported and determined by strong economic business institutions, adequate supporting facilities and infrastructure that can affect the price of food so that it can be accessed by the community. Existing institutions should play an active role in providing food so that the food reaches consumers in sufficient, timely, quality, and affordable levels of public purchasing power.

Food distribution as part of the food security system is understood as the activity of regulating, predicting and facilitating so that food can be distributed from production sites to consumption locations. Steps taken in the context of food distribution, institutional development, food distribution and control of food prices.

The existence of a food distribution institution is very important in order to guarantee the pattern of food distribution. In TTS district food distribution institutions consist of; (1) farmer groups; (2) farmer groups; (3) farmer cooperatives; (4) village unit cooperatives; (5) community food storage; (6) rice milling businessmen. The existence of this group is very beneficial because this institution is the main actor partner who performs the function of distributing food from food producers to food consumers. 


\section{Food Consumption}

The food consumption is one aspect that affects the condition of the food security system. Sufficient food consumption for households or individuals illustrates the food security of these households.The instrument used to analyze the level of food consumption of the community is to use the Hope Food Pattern analysis, through this analysis it is known about the level of food availability and consumption.

The results showed that the pattern of food consumption in the Timor Tengah Selatan regency had reached 1,637 kcal / capita / day. When viewed from the percentage of diversity, the contribution of each food group is still below the AKG standard (Nutrition Adequacy rate), meaning that food consumed by the community is still below the AKG standard.

On the other hand there are several problems related to food consumption in the Timor Tengah Selatan regency, namely; (a) limited facilities and infrastructure and human resources to conduct studies on consumption, quality, and food security; (b) limited availability of data / information about the development of food consumption;(c) action studies have not been carried out on the results of motivational activities and community participation. 


\section{Conclusion}

A system is a network of interacting components that together form a complex whole. The food system is a system encompassing all the activities and resources tha go into producing, distributing, and consuming food. Food systems are shaped by a multitude of factors, such as geography, demography, urbanization, and globalization; socioeconomic status and income, marketing, and consumer attitude; and religion and culture. These factors impact also food security at national, local, and household level. (Kearney, 2010).

The food system consists of sub-systems that can be elaborated into compartmentalized areas of production, consumption, and nutrition and defined the key determinants of each area: food production (agriculture, food storage and processing, distribution, wholesaling and retailing, and food marketing); food consumption (food quantity, food availability, food quality, food affordability, dietary diversity, dietary habits, cultural and social influences, taste and enjoyment, and physical environment); and nutrition (balanced diets, malnutrition, and wellness). In doing so, they stressed the importance of connecting production and consumption while considering the far-reaching implications of food systems in terms of nutrition and health (El Bilali at al, 2018).

The condition of local food security in Timor Tengah Selatan regency is vulnerable so that this situation has the potential to have implications for local communities. However, the resilience system in Timor Tengah Selatan regency has not caused very bad implications, for example, deaths due to food shortages. The various ways they do to maintain the situation, so that they do not experience hunger, namely; (a) the local community has a food storage system in the face of the drought; (b) the community has a traditional communication system to distribute food when the condition of the food distribution infrastructure is inadequate through a symbolic interaction culture model. Messages about the problem of food shortages and distribution are delivered through inter-clan deliberations with the momentum of "family gathering"; (c) Local people in Timor Tengah Selatan district have traditional ways of processing local food ingredients into a menu of dishes that have high nutritional value. Either example of local cuisine from local food is "Jagung Bose". 
Proceeding ICOGISS 2019

Page 65-80. ISBN: 978-602-6 988-75-1

Web Jurnal Online: jurnal.unmuhjember.ac.id

By: Nursalam

The Local Food Security System In Regency of

Timor Tengah Selatan (TTS)

\section{References}

Badan Tanaman Pangan Kabupaten Timor Tengah Selatan, 2018, Laporan Tahunan.

Bingxin Yu.,Lingzhi You., Shenggen Fan, 2010, Toward a Typology of Food Security in Developing Countries, IFPRI Discussion Paper 00945, Washington, International Food Policy Research Institute.

Clay, E. 2002. Food security: Concepts and measurement. In Trade reforms and food security: Conceptualising the linkages. Rome: Food and Agriculture Organization of the United Nations.

Creswell, J.W. 1994. Research Design Qualitative and Quantitative Approach. UK-New Delhi-California : Sage-Publication.

Denzim, Norman K., Yvonna S.Lincoln (eds), 1994, Handbook of Qualitative Research, London, Sage.

Dreze, Jean and Amartya Sen, 1989. Hunger and Public Action, Oxford: Clarendon Press.

El Bilali, Hamid., Carolin Callenius., Carola Strassner, Lorenz Probst, 2018, Food and nutrition security and sustainability transitions in food systems, Food and Energy, Doi:101002/Fes 3.154, John Wiley \& Sons Ltd.

Lassa, Jonatan, 2009. Diskursus Kelaparan dan Ketahanan Pangan Indonesia 19582008: Studi Kasus Nusa Tenggara Timur, dalam 50 Tahun Ziarah Pangan Nusa Tenggara Timur Jonatan Lassa, Dion DB Putra, Tony Kleden (Editor), Kupang: PT Timor Media Grafika

Kearney, J. (2010). Food consumption trends and drivers. Philosophical Transactions of the Royal Society of London. Series B, Biological Sciences, 365, 2793-2807. https://doi.org/10.1098/rstb.2010.0149

Maxwell, Daniel G,1996.Measuring food insecurity: the Frequency and Severity of Coping Strategies, Food Policy, 21 (2):291-304.

Safrizal, 2009, Penguatann Ketahanan Pangan Daerah: Studi Tentang Revitalisasi Kelembagaan Ketahanan Pangan Masyarakat Gampong di Kabupaten Aceh Besar, Tesis, UGM, Yogyakarta.

Sukiyono, Ketut., Septri Widiono., Indra Cahyadinata.,Sriyoto, 2009, Kajian Tentang Local Concept Ketahanan Pangan dan Probabilitas Terjadinya Kerawanan Pangan Rumah Tangga (Studi pada Rumah Tangga Nelayan dan Petani padi di Kabupaten Mukomuko Provinsi Bengkulu, Laporan Hasil Penelitian, Universitas Bengkulu.

Sutoyo, Adi, 2013, Implementasi Program Aksi Ketahanan Pangan di Provinsi Bengkulu, DIAJurnal Administrasi Publik Vol 11 No.1 halaman 93-116.

Timmer, C Peter, 2005, Food Security and Economic Growth: an Asian Perspective, in Asian Pacific Economic Literature, 19 (1): 2-3.

Tim Peneliti Pangan IPSK-LIPI, 2001, Penerapan Kebijakan Pangan Bagi Pencapaian Kedaulatan Pangan, Makalah yang Disampaikan pada Kongres KIPNAS, LIPI, Jakarta. 